Illinois State University

ISU ReD: Research and eData

Theses and Dissertations

3-25-2021

\title{
The Value of an Anthropology Degree: Why Undergraduates Major in Anthropology and How It Prepares Them for Life After College
}

Maria Kitchin

Illinois State University, mariakitchin@gmail.com

Follow this and additional works at: https://ir.library.illinoisstate.edu/etd

\section{Recommended Citation}

Kitchin, Maria, "The Value of an Anthropology Degree: Why Undergraduates Major in Anthropology and How It Prepares Them for Life After College" (2021). Theses and Dissertations. 1445.

https://ir.library.illinoisstate.edu/etd/1445

This Thesis is brought to you for free and open access by ISU ReD: Research and eData. It has been accepted for inclusion in Theses and Dissertations by an authorized administrator of ISU ReD: Research and eData. For more information, please contact ISUReD@ilstu.edu. 
THE VALUE OF AN ANTHROPOLOGY DEGREE: WHY UNDERGRADUATES MAJOR

IN ANTHROPOLOGY AND HOW IT PREPARES THEM FOR LIFE AFTER COLLEGE

\section{MARIA KITCHIN}

\section{Pages}

"What are you gonna do with that degree?” is a question frequently asked of anthropology majors. This question implies that the value of a college degree is only about getting a job and that the field of anthropology is not useful to that end. In fact, the popularity of anthropology and related liberal arts fields has been declining even as the number of students enrolled at universities has steadily increased. In a moment when the value of a liberal arts degree is questioned in public discourse, I explore the motivations and goals of students who have chosen to study anthropology at large, public predominantly undergraduate university in the Midwest. Interviews with current students and recent alumni show that students value anthropology because it encourages personal growth and instills them with an eclectic knowledge of the world. Additionally, students appreciate that anthropology does not make them think vocationally about their degree. Instead, it allows students to imagine many future paths because it provides them with a variety of broadly applicable skills. This research offers insights into students' understanding of the purposes of higher education, and their study of anthropology, and the ways they see their degree as it pertains to life after college.

KEYWORDS: Anthropology, Liberal arts, Neoliberal, University, Undergraduates 
THE VALUE OF AN ANTHROPOLOGY DEGREE: WHY UNDERGRADUATES MAJOR IN ANTHROPOLOGY AND HOW IT PREPARES THEM FOR LIFE AFTER COLLEGE

\author{
MARIA KITCHIN
}

A Thesis Submitted in Partial Fulfillment of the Requirements for the Degree of

MASTER OF SCIENCE

Department of Sociology and Anthropology

ILLINOIS STATE UNIVERSITY 
Copyright 2021 Maria Kitchin 
THE VALUE OF AN ANTHROPOLOGY DEGREE: WHY UNDERGRADUATES MAJOR IN ANTHROPOLOGY AND HOW IT PREPARES THEM FOR LIFE AFTER COLLEGE

MARIA KITCHIN

COMMITTEE MEMBERS:

Gina Hunter, Chair

James Stanlaw 


\section{ACKNOWLEDGMENTS}

Thank you to all the faculty and staff in the Department of Sociology and Anthropology who have enriched my life, and this work, with their talent as educators.

My deepest gratitude to Dr. Gina Hunter, who changed the trajectory of my life with the offer to conduct this research. Thank you for all the opportunities you have brought to me and for trusting in my abilities. Your guidance and advice have been invaluable to me and to this project. I am ever grateful to have had such a confident, intelligent, empowered woman as my mentor. It has been an honor to work so closely with you.

A special thanks to Dr. Stanlaw, the professor who introduced me to the depths of anthropology. The tools I've gained under your tutelage have become some of my greatest tools for navigating this world. You have been my constant supporter and cheerleader. Thank you for believing in me.

I give my heartfelt thanks to Abigail Xue Ma, my research associate who worked tirelessly on the data collection and transcription of interviews. Xue, your support throughout this process of research and presentation has been irreplaceable. And thanks to our classmate, Alexis Lange who worked closely with Abigail Xue and I in the Spring of 2019.

I am ever grateful to the staff at the American Anthropological Association that founded and organized this project. Daniel Ginsberg, I appreciate all of your leadership throughout these years of research, your continued collaboration, and your guidance during our presentations. Palmyra Jackson, this project could not have been successful without your coordination. Thank you both for providing this opportunity and believing in this project.

M. K. 


\section{CONTENTS}

Page

ACKNOWLEDGMENTS I i

CONTENTS

CHAPTER I: INTRODUCTION 1

CHAPTER II: REVIEW OF RELATED LITERATURE 4

Anthropology and Liberal Arts Education in the United States 4

$\begin{array}{ll}\text { Liberal Arts Education in a Post World War II America } & 6\end{array}$

$\begin{array}{ll}\text { Anthropology Programs in the Neoliberal University } & 10\end{array}$

The Profile of Anthropology Students in the US 12

Theories of College Student Development and Choice of a Major 15

$\begin{array}{ll}\text { Communities of Practice } & 18\end{array}$

$\begin{array}{ll}\text { CHAPTER III: FIELD SITE AND METHODS } & 20\end{array}$

CHAPTER IV: DATA AND ANALYSIS 24

$\begin{array}{ll}\text { The Case of Jared } & 24\end{array}$

$\begin{array}{ll}\text { The Case of Lola } & 29\end{array}$

Finding Anthropology 33

Why Undergraduates Choose Anthropology 35

“Learning from each other:” Community of Practice Among Anthropology Students 39

“A time of personal growth:” How Anthropology Changes Students 43

“There’s a lot you can do with it:” Students Talk About Life After College 45

CHAPTER V: CONCLUSIONS 49

REFERENCES 


\section{CHAPTER I: INTRODUCTION}

The university is a place to discover inner passions, learn about the world, and expand student perspectives. Liberal arts fields, such as anthropology, explicitly promote these values in students; however, over the past several decades, the value of a degree in the liberal arts has been questioned. Although a college degree is seen as a prerequisite for middle class life and a path towards social mobility, the value of the liberal arts’ broad, worldly curriculum has been questioned and compared to the specialized, career-directed approach of other majors. This is reflected in the university's emphasis on vocational degrees (such as business, engineering, and

nursing). The university has become an institutionalized preparation for the work force. Both the high tuition rates and the expectation that college is the first step towards a career, pressure students to choose a career-ready degree. So, in a moment when this is the expectation of students, why do some choose to pursue a degree such as anthropology? And what do students plan to do with their degree?

In this thesis, I answer these questions using qualitative, ethnographic data that I collected at Illinois State University’s Department of Sociology and Anthropology between 2018 and 2021. I begin by reviewing related literature. I introduce anthropology as an example of a degree in the liberal arts and sciences, explain its foundational role in American higher education, and outline the arguments against its value. This history provides context for the subsequent sections about choosing a major and the profile of anthropology students.

As I present the data, I explore major themes of my research such as how students become familiar with the field of anthropology and what they believe their major will mean to them in life after college. My interviews explored how students encountered the major (and how some struggled when they declared the major), how they came to see its value, how 
anthropology enhanced their personal growth in college, how students became part of communities of practice at Illinois State and the field of anthropology more broadly. My interviews also revealed student's plans, or lack thereof, after graduation and how students thought that anthropology would matter in their lives beyond college. While students' stories are unique, I discovered that students value the broad education they receive via anthropology. I present student narratives to show that those who major in anthropology view college as a time to better themselves, learn about the world, and acquire general skills that will help them in the future. Many anthropology students were focused on being a student and had not chosen a specific career path (yet). They did not take a vocational approach to their undergraduate education. I conclude that students value anthropology not because they aim to be a professional anthropologist, but because it offers a broad, liberal arts education that develops students' sense of self and position the world.

I contextualize these claims by building on theories of student development, research on the neoliberal university, and decades of qualitative data on choosing a major (Arnett 2019; Breitborde 1989; Goldmacher 2011; Gusterson 2017; Standing 2011). Theories of major choice, emerging adulthood, and cosmopolitanism help to explain my ethnographic data (Arnett 2019; Brenna 1997; Caine 2010). These theories add context to students who talked about college as a space for self-discovery, the choice of an anthropology major as an act of agency despite constraints, and anthropology as a means to feeling at home in the world. These themes, and the accompanying theories, support my findings that students value the broad, liberal arts education they receive in anthropology.

The research for this thesis began as part of a multi-sited project coordinated by the American Anthropological Association. The goal of the AAA project was to describe 
undergraduate anthropology students' experiences at a number of institutions across the U.S. As part of the AAA research project, I joined virtual periodic conference calls with four groups of students conducting similar research on different campuses (Indiana University, University of Louisville, Wheaton College, Saint Mary’s College of Maryland). In these virtual meetings, we discussed our separate research strategies (other researchers used focus groups, surveys, and interviews with Career Center staff), our findings, and our interactions with our peers. Hearing the experiences of other AAA Research Fellows helped me understand that complex relationships between peers exist across campuses and universities. Working with these student research, as well as my own peers, helped direct my own future path towards a graduate degree and a future in education. 


\section{CHAPTER II: REVIEW OF RELATED LITERATURE}

\section{Anthropology and Liberal Arts Education in the United States}

Anthropology offers some specific skills—notably cross-cultural understanding - that students at Illinois State value. Other attributes that students identified, such as anthropology’s broadness and applicability to many spheres of life, might be seen as characteristics of a liberal arts education. American anthropology at the undergraduate level with its "four-field" comprehensiveness is a quintessential example of a liberal arts degree. My research shows that students desire this broad, flexible major despite public discourse that questions the value of the liberal arts. It is important therefore to situate anthropology within the context of broader trends in American higher education, in particular, the impacts of neoliberalism.

The term "liberal arts" refers to a model of education that emphasizes critical thinking skills and knowledge of behavior, culture, history, human achievement (Breitborde 1989). Liberal arts education has ancient roots. Its origin can be traced back to ancient Greece (400 BCE) when the value of writing, logical thought, and critical rhetoric were considered essential training for citizens (Brighouse 2019; Katerberg 2016). This training included an emphasis on reason and rationality and is associated with the Greek ancient philosophers Plato and Aristotle. This practice of teaching migrated to ancient Rome where, during the Renaissance, it became known as “liberales artes” or unrestricted study (Katerberg 2016; Merriam-Webster 2021).

American universities are founded on the ideal of a liberal arts education. The traditional role of the University was to encourage curiosity and provide students to with an interdisciplinary knowledge (Gusterson 2011). The liberal arts have been foundational in American higher education (Thelin 2004); in the first three decades of the 1900s, upwards of 
seventy percent of college graduates attained a degree in liberal arts fields: literature, philosophy, sociology, anthropology (Ferrall 2011).

Although a relatively young discipline, anthropology has been a significant field of academic research and publications (Ferall 2011; Voegelin 1950). Anthropology did not emerge as an academic discipline in Europe until the 19th century when the work of Charles Darwin and archeologist Christian Thomsen were accepted by the scientific community (Microsoft Encyclopedia 2003). Anthropology, the study of human variation, was often distinct from Ethnology, the study of so called aboriginal and primitive [sic] cultures. These fields merged in the discipline of anthropology as it developed in the United States (Tax 1977). American Anthropology can be defined as the study of human culture, communication, artifacts, and biology.

While anthropology in the American universities can be traced back to 1885, it became widely popularized and professionalized in the 1920s by Franz Boas, who held the first professorship of anthropology at Columbia University. For this reason, he is called the father of American Anthropology (Microsoft Encyclopedia 2003; Voegelin 1950). Between 1900 and 1920, American universities offering anthropology courses steadily increased and anthropology held some of the highest numbers of degree recipients (Voegelin 1950). At this time, however, although the number of anthropology degree was steadily increasing, debates about the purpose of the liberal arts in the university were already emerging (Voegelin 1950).

This history is important because concerns about the "death of the liberal arts" are often understood as a recent crisis, but they have been circling in academic communities since the early 1900s (Ferall 2011; Voegelin 1950). The debate about the value of the liberal arts has 
intensified with the growth of professional education in business, industry, and STEM fields which expanded rapidly in the post-WWII America.

\section{Liberal Arts Education in a Post World War II America}

In the wake of World War II (after 1945), a number of shifts occurred at American universities that changed their student populations and their role in society. In particular, universities were increasing sites for contributing to war efforts and military advancements and as engines of economic, and scientific advancements. Funding and research grants were primarily awarded to STEM fields, leaving the liberal arts with less resources.

This shift was also impacted by political influences on universities. Hugh Gusterson’s Homework: Towards a Critical Ethnography of the University (2017) reminds anthropologists that understanding the current position of the discipline begins with looking at the history of the Cold War (beginning in 1947 and lasting until 1991). During World War II, the role of hard science was undeniable in the success of the United States. When the Cold War began, only two years after the end of World War II, the National Science Foundation and Department of Defense funded research projects (several of which remain classified) at American universities including MIT, John Hopkins, and Stanford (Gusterson 2017). This sudden influx of generous research funding quickly expanded these universities' science and engineering departments. Gusterson explains, in the 1960s over half of the funding for the top six United States universities was supplied by Cold War defense contracts. In other words, “the Cold War stimulated a substantial expansion of the US [undergraduate] university system” (Gusterson 2017). Essentially, the university became responsive to governmental defense and corporate needs; this, in turn, changed the reward structure of the university. The university became less concerned with teaching and more concerned with getting grant money and achieving publications. 
As the Vietnam War began, ten years after the end of World War II, the demand for higher education changed and it became commonplace for universities to admit women, Jews, and black students - all previously disallowed from pursuing higher education (Ferrall 2011). Diversified admissions changed college campuses and a degree became a motor of social mobility for the expanding post-war middle class. College-bound students began to associate a degree with better job security and more financial success (Ferrall 2011).

Changes in the labor market and economic prospects marked a change in the types of degrees university's offered. Subsequently, universities that offered plentiful liberal arts courses (predominantly prestigious schools) struggled to receive enough applicants to keep the university functioning. In response, these universities increased their practical application classes, such as “business, nursing, criminal justice” (Ferall 2011). Henry Heller’s The Capitalist University (2016) explains that the university has transformed from an arena for exercising curiosity and achieving self-betterment to a place for professional development. This demand for vocational degrees has remained present in higher education. Universities' investments in professional and technical education and government support for sciences and technology explain the declining interest in the liberal arts fields.

The contemporary social and economic system has presented additional challenges to traditional liberal arts programs and their would-be students. These challenges have been described as resulting from neoliberalism and its impact on universities (Gusterson 2017). Neoliberalism, defined by Gusterson as, "a political-economic system marked by inequality and precarity that shifts the risk to workers and wealth to elites while turning formerly public goods into private profit centers," emphasizes “casualized labor, and ideologies of individual responsibility” (2017, 439). The modern university has become “neoliberal.” Neoliberal 
practices are exemplified at universities as a decline in state funding compensated through increasing tuition rates, the reshaping of higher education as training for corporate professionalism, a restructuring of the university workforce, and the instrumentalization of the university as a tool to accumulate capital (Gusterson 2017).

These workforce adjustments are exemplified by a decrease in tenured track professors, the increase of adjunct faculty, the underpayment and increased workload of graduate workers, and an increase in tuition (Gusterson 2017). These are examples of the university's casualization of labor and shifting the financial risk onto the individual (instead of the institution they work for, attend, or represent).

Individualized financial risks are also exemplified through increases in tuition, increases in the number of out-of-state students, as well as international students' universities recruit. These students are required to pay the full unsubsidized tuition price (Redden 2019). In order to attract more out-of-state students, universities are inclined to slacken their academic requirements, invest in recreation and sports, and market themselves as the place for an unforgettable ‘college experience’ (Armstrong 2013). These faculty, student, and tuition restructurings have positioned the university as a system to gain financial capital (Gusterson 2017).

Drew Gilpin Faust’s “The University’s Crisis of Purpose,” discusses this from the perspective of those working within higher education (2009). Faust believes the university has become captive to the immediate and worldly purposes they serve. The neoliberal climate has contorted the modern higher education system into a skewed system of preparation for the workforce. The traditional value of learning for the sake of curiosity and critical thinking has become underappreciated, inaccessible, and perceived as impractical. Faust proposes, "has the 
market model become the fundamental and defining identity of higher education?” This echoes Gusterson's point about universities focusing on breeding corporate professionals (2017). The underlying question here becomes: what is the value of higher education in a nonprofessionalized degree?

Standing (2011), in his book, The Precariat Charter, describes some of the problems of higher education from the perspective of students as the future workforce marked by precarity. Standing points out that institutions offering bachelor's degrees entice students in with promises of job security but leave them with insurmountable amounts of personal debt in an economy that is not built to support their financial needs (2011). Like Faust, who questions how the university will benefit those interested in receiving a non-professionalized education, Standing questions the value of a bachelor's degree in a moment when the debt will outweigh the supposed financial benefits of being a degree holder (2011).

Today, American universities continue to debate the value and purpose of a liberal arts education (Gusterson 2017). While professional and technical fields continue to accrue funding through grants and contracts, state funding continues to shrink resulting in steep tuition increases. To account for this, universities have developed new ways of expanding revenue such as hiring recruiters to increase the number of students paying higher tuition prices (i.e., international students, out-of-state students), relaxing academic standards, and reshaping the university workforce (Redden 2016; Gusterson 2017). These characteristics are quite different from the traditional values of a university: to provide affordable education to provincial students (Gusterson 2017). Such structural changes within the university can be attributed to the contemporary neoliberal climate, characterized by social and political support to increase freemarkets, globalize the economic system, and further economic stratification. 
The neoliberal era has caused far reaching changes for American higher education. In a time when the value of a liberal arts degree is being questioned and universities are being restructured to fit the neoliberal political-economic circumstances, it is unfortunate that many college students and educators have become complicit in the process by accepting higher education narrowly as job preparation.

\section{Anthropology Programs in the Neoliberal University}

Given the historical shifts above, it also follows to question why students in this context decide to major in anthropology or other liberal arts fields. For decades, universities have debated the value of an anthropology degree.

In the 1980s, university professionals debated whether anthropology was considered “pre-professional development” or "liberal arts education” (Breitborde 1989); this is due to the variety of subject matters covered in anthropology’s archeological, biological, cultural, and linguistic subfields. For instance, because of the relationship to lab science, archeology and biological anthropology are were seen as a "professional-track" degree whereas cultural and linguistic anthropology were viewed as part of the liberal arts. The categorization of anthropology under these terms, "pre-professional” or “liberal arts,” was enforced by university deans, whose professional language determined the perception of the degree among university faculty, students, and donors.

L.B. Breitborde, an anthropologist at Beloit College, a midwestern institution, set out to understand the language of academic deans and how language influences the perception of particular degrees (1989). His work compared four competing models of the anthropology major. These models were central to discussions of the major's label at the time. Breitborde compared 
the experiences of anthropology undergraduates, faculty, and academic advisors to that of the deans.

Breitborde discovered that academic deans were influenced by government-sponsored reports on higher education in the United States — specifically, the Carnegie Foundation's reports. These reports affected the development of liberal arts programs at a variety of US higher education institutions (Breitborde 1989). This is a continuation of the lack of university support for liberal arts education explained by Gusterson (2019) and Ferrall (2011). Breitborde’s research says that university professionals were influenced to financially support the development of vocational programs. This posed a question for anthropology, because it was unclear if the subject was categorized as professional development or liberal arts (Breitborde 1989).

The influence of Carnegie Foundation reports can be traced back to the 1950s. In 1963, twenty-five years before Breitborde’s research, the American Anthropological Association’s Teaching Anthropology published an article by Vern Ray critiquing the role of anthropology in modern education. Ray references the 1956 Carnegie Foundation report that declares, “(1) a liberal education instills knowledge that an educated person must have (including the biological and psychological roots of behavior; knowledge of the physical and biological world; an understanding of one’s own and other cultures; a history of human achievements, intellectual and artistic; and appreciation of our religious and philosophical heritage); and (2) a liberal arts education should instill critical thinking and comprehension skills.” Ray uses this report to support his claim that anthropology, regardless of its label as "pre-professional” or "liberal," meets the Carnegie Foundation’s criteria for a liberal arts education. 
Breitborde cites this example because it emphasizes the mission of a liberal arts education over the organization of a department or a specific undergraduate program. That is to say, variation among departments is unavoidable with anthropology's multiple subfields and myriad material, but such variation does not affect undergraduate students' ability to progress academically and receive a liberal arts education. In his conclusion, Breitborde explains that the faculty of the anthropology department must speak "the language” of the university deans in order to continue the development of their program. In other words, since the deans expressed interest in vocational programs focused on professional development, advocates for anthropology can support this label, while continuing to instill the values of a liberal arts education in students (Breitborde 1989).

Anthropology holds a unique position in the liberal arts because its four subfields archeology, biological, cultural, and linguistic — straddle (both the areas and the arguments surrounding) the hard sciences, social sciences, and humanities. This unique position does not exempt anthropology from the scrutiny liberal arts programs have been facing since the 1960s. A liberal arts degree has transformed from the coveted model of education to an experience widely considered less practical and, therefore, less valuable than a vocational degree (Ferrall 2011; Goldmacher 2011). In today’s neoliberal environment, anthropology undergraduates, professors, and administrators continue to fight against the declining demand for liberal arts education (Ferall 2011).

\section{The Profile of Anthropology Students in the US}

Although the neoliberalization of the university has a major impact on the number of students in the liberal arts fields, research conducted by the American Anthropological Association confirms that within the social sciences, "anthropology is holding its own" 
(Ginsberg, 2017, 1). The decreasing number of anthropology graduates is certainly due to changes in the number of majors, not to the number of departments offering the degree, as the number of such departments has increased since 1987 (Ginsberg 2017).When compared to other social science fields such as political science, criminology, economics, sociology, and history, anthropology has a smaller number of graduates. It surpasses geography, urban studies, and archeology in its undergraduate certifications. This may be linked with the student perception that anthropology (as well as geography, urban studies, and archeology) are not career-ready disciplines. The study suggests that students interested in the social sciences are more likely to choose political science, criminology, or economics because they are perceived as "preparation for jobs in business or law enforcement” (Ginsberg 2017, 5).

A bachelor's degree in anthropology is not a direct path to a career. In fact, a report by The U.S. Department of Education explains that the majority (59\%) of anthropology students have no plans to pursue a graduate-level degree (Choy 2008). This finding suggests that the majority of anthropology undergraduates are not planning to become a professional anthropologist or pursue a career in academia.

Given the push towards vocational degrees and the growing perception that anthropology is not "career-ready," why are students choosing to major in it? Of course, this answer varies and is informed by social factors. Let us first answer: what kinds of students are majoring in anthropology and why? According to Ginsberg's research, gender, race, and type of university are three major factors in students' decisions to major in anthropology. The majority of anthropology degrees between 2003-2016 were obtained by white (73\%), female students (73\%) that attended privileged, highly selective, inaccessible universities (65\%) (Ginsberg 2017). Efforts have been made to diversify students in anthropology with some apparent success 
(Ginsberg 2017). Since 2003, both the black and Asian student body has increased by $163 \%$ and the LatinX student body has increased by $249 \%$ and are trending upward; however, with the (71\%) white student population growing at a $124 \%$ rate, the major remains largely white and female Therefore, white women from privileged backgrounds are dominant in the anthropology major.

According to data collected by the American Anthropological Association, the number of anthropology majors has been on a steady decline since 2013; however, the number of undergraduate degrees received across the country continues to increase annually (Ginsberg, 2017). In other words, although university populations are larger than ever, students are less inclined to study anthropology. One reason is that they may feel pressured to choose a major that will lead to an immediate, financially-secure occupation. Guy Standing argues that insecure job prospects are especially likely for graduates who are navigating a professional world that values 'practical' degrees over a liberal arts degree.

Additionally, one 2018 study of undergraduates with degrees in the humanities (Choy and Bradburn 2008) reported that over one-third of humanities graduates did not see a correlation between their degree and their current work. This lack of coordination between degree and career may be a growing reality for an increasing number of college graduates. One the other hand, the Institute for the Future (IFTF) predicts that $85 \%$ of the jobs available in 2030 do not even exist yet. This may bode well for students in the liberal arts generally, and anthropology degree holders in particular because, as Ginsberg argues, anthropology students are broadly prepared (Ginsberg, 2019). Given the increase in technologically dominated fields, the growing expectations of not yet invented professions, and the continually shifting job market, a case can 
be made for the importance of degrees that focus on critical thinking, communication, and other transferable skills.

Trends in the types of students in the anthropology major reflect the trend of the larger liberal arts field. Although, anthropology may be suffering in number of graduates, those that do choose anthropology have broad career options (Ginsberg 2019). Ginsberg argues, "anthropology is a job-ready major that provides training for a wide range of meaningful careers” in fields such as advertising, business administration, education, museum and cultural preservation (Ginsberg 2019, 12). This argument supports some of the examples this paper provides about Illinois State University students and their plans for life after studying anthropology in college.

\section{Theories of College Student Development and Choice of a Major}

Upon entering university, students, typically eighteen years of age, are confronted with a major decision: choosing a degree. For undergraduate students, college is a liminal space, a time between adolescence and adulthood (Arnet and Murray 2019). The liminality of college encourages personal growth and self-discovery (Arnet and Murray 2019). When students are choosing their degree, they are thinking about how they want to grow over the course of their college career. While attempting to decipher their role as a budding adult, students are expected to decide a future path in the form of a major. Not only are personality and environmental factors at play, but structural and identity-based factors which impact student's choices.

First, I will examine a psychological theory of personality-based choice. This is a rationalist, individualist choice framework that is at odds with a socio-cultural approach to “choice.” The authors of Decision-Making Styles in a Real-Life Decision: Choosing a College Major consider personality traits as a determining factor in choice of major. The authors 
categorized results using a metric of five types of decision makers: rational, intuitive, dependent, avoidant, and spontaneous. These categories were based on a preceding psychological proposal by psychiatrists' Scott and Bruce in 1995 (Galotti 2006; Loo 2000). Findings conclude that regardless of the decision-making category (i.e. rational, intuitive, etc.), when choosing a major, students collect information and deliberate in a similar, consequence-based approach. The difference exists in the "degree to which they extrapolated the consequences of their decision into the future, or to their principles and values” (Galotti 2006, section 4). These findings suggest that the individual's choice of major is connected to that individual's conception of their future.

A socio-cultural approach to "choice" suggests that the choice of major is not offered with equal opportunity to each student (Mullen 2014). Student’s backgrounds and identities inform and limit their decisions. A number of authors show that the majority of liberal arts students coming from privileged backgrounds (Ferral 2011; Goldmacher 2011; Mullen 2014).

Sociologist Ann Mullen (2014) challenges the dominant idea that a student chooses a major in order to prepare for a specific degree. Instead, she suggests that gender and socioeconomic background influence students' choice of major, in particular she found that students from privileged backgrounds, attending prestigious universities, are the likeliest to follow the traditional gender associations (Mullen 2014). Mullen argues that an individualist, career-oriented perspective on major choice (such as the Galotti study) ignores the complex social inequalities present in both vocational and liberal arts contexts (2014).

According to Mullen's research, men are unlikely to pursue their intellectual interests. In fact, the proportion of male students in anthropology has been steadily declining since 2003 (Ginsberg 2017). Mullen suggests that this is because of the American cultural expectation on men to be financially secure (Mullen 2014). Men choose to major in a subject generally 
perceived as a "safe” or "lucrative” career path (Mullen 2014, 307). Women, typically from privileged backgrounds, are more likely to major in a subject each finds intellectually stimulating and plan a future career after that decision.

Mullen's conclusions reflect the quantitative research of Ginsberg (2019). That is to say, both studies indicate that men, people of color, and students attending less selective universities are more likely to choose a major that will "lead to an immediate, well-paying job” (Ginsberg 2017, 5; Mullen 2014). Not all students who are captivated by anthropology, or other liberal arts disciplines, have the ability to pursue it because of the (financial and social) pressure to secure a financially secure job.

Mullen’s findings expand on Goldmacher and Farell's research by insisting that gender, as well as class, are unignorable factors in the decision of choosing a major. This is to say that students are not "free" to "choose" any major. Identity factors such as gender, class, and race impact students’ degree (Ginsberg 2019; Mullen 2014). Students who study anthropology are privileged to "choose" the major.

Anthropologist Amy Goldmacher studied anthropology majors in depth (2011). Goldmacher's research was conducted between 2008 and 2011, in the wake of the 2008 recession. At this time, anthropology students who could afford to attend university without worry about future job prospects and dealing with insurmountable debt came from privileged backgrounds. Goldmacher found that the two main draws to anthropology were the degree's ability to satisfy students desire to learn about the world and the people in it and also the institutional requirements that made it easy for students to double major. Additionally, she found that students internalize conflicting values of anthropology and neoliberalism. Due to this, students feel they have to choose between pursuing anthropology or making a living 
(Goldmacher 2011, 116). I will build on her findings and show that for ISU students, they do internalize mix messages about the value of their degree, but they have faith that anthropology will lead them to a successful career.

\section{Communities of Practice}

Part of becoming a major is learning to think, work, and behave as a member of a community of practice. A community of practice refers to a "group who share a common interest and desire to learn from and contribute to the community with their variety of experiences” (Lave and Wenger 1991). Communities of practice bond over a shared passion and learn how to be better at that passion through interacting regularly (Lave and Wenger 1991). A community of practice is formed when people engage in collective learning and practice in a shared domain, such as a shared building, title, or experience. Undergraduate students participate in this collective learning in the domain of their major.

This major becomes a space for students to be practicing members of a community. For instance, when students stay after class to converse with fellow classmates and teachers, although they may not realize it, this practice is one of their main resources for getting advice, understanding course material, choosing future classes, and thinking about career plans. In the course of these conversations, students build a set of stories and cases that become a shared repertoire for understanding the community of the major (Lave and Wenger 1991). Students also practice community in intentional ways such as joining a major-related club or organization.

Communities of practice focus on the social dimensions of situated learning which is a theory that explains the development of skills. Situated learning shows that students acquire professional skills through apprenticeship. Students begin as peripheral participators, and this evolves into proficiency and direct participation. Students use the skills they learn to contribute 
to the community and develop their identity as a member of the major. This is true for anthropology students, who begin as apprentices until they develop the skills to conduct their own research and identify as anthropologists.

At Illinois State, although no student used the words “community of practice” to describe their experiences, it was clear that the feeling of belonging in the community was a component of why some students chose to major in anthropology. The community of practice theory illustrates how continued learning and socialization influences student identities and student's changing positions (Lave and Wenger 1991). 


\section{CHAPTER III: FIELD SITE AND METHODS}

I collected ethnographic data for this thesis at Illinois State University, a mid-size public university established in the heartland of Illinois in 1857. Today, the school is a predominantly undergraduate, Carnegie classification “R2,” or “research-intensive” institution with 20,000 students, offering degrees in diverse majors, from business and education to studio and liberal arts.

At Illinois State University, the Anthropology Program is a four-field program located within a combined Department of Sociology and Anthropology. The Program has eight tenure line faculty (of 24 in the Department) who offer all of the required courses for the major and teach large general education courses. Although the program is part of a combined department, the Anthropology Program offers “four-field” anthropology curriculum which requires students to enroll in courses that fall into each of the discipline's four main subfields: biological, archaeological, linguistic, and cultural anthropology. As of Spring 2020, the program had 75 declared majors and 33 minors. Anthropology also has an Accelerated Master’s Program (a “4 years plus 1”) and an MA program with 19 graduate students.

Although anthropology courses have been offered at Illinois State since at least 1950 as part of social sciences and education degrees, additional anthropology courses were added during the late 1960s when college student populations dramatically increased, and university programs expanded in Illinois as throughout the nation (Thelin 2004). Prior to this, Illinois State Normal University was, like many state colleges, primarily a teacher preparation college. In 1967, in what was perhaps a reflection of its expanded programs, the University dropped "Normal” from its title and became Illinois State University (“Illinois State Normal University” 2021). A major 
in anthropology (as a sequence in the Department of Sociology and Anthropology) first appears the University Catalogues in 1973.

Today, the requirements for a bachelor's degree in anthropology include 25 hours of required courses, 15 hours of electives, and a senior thesis ( 40 hours total). One of the required courses is a one-hour careers course meant to help student envision their life after college and familiarize students with on-campus resources such as the career center. At the time of this fieldwork, the Program had recently implemented curriculum reforms, including greater flexibility in the selection of elective courses, in an effort to attract more majors to the program.

Today the Department is housed on the north east side of the ISU quadrangle, in Schroeder Hall, where there are department and faculty offices, classrooms, and laboratory spaces. Participant observation was conducted within the classrooms of Schroeder Hall. Here, also, I built connections with my peers and found interviewees for my research.

My data include personal narratives of anthropology students obtained through face-toface, one-on-one, semi-structured interviews; field-notes taken at department events, and informal conversations with department faculty and the academic advisor. The research for this thesis was conducted between fall 2018 and spring 2021.

In Spring 2019, I, the primary investigator, worked with one first-year graduate student (Xue Ma) and another undergraduate (Alexis Lange) to conduct interviews among twenty-two of our peers in the department regarding their perception of an undergraduate anthropology degree and plans for life after college. Participants were recruited via word-of-mouth, flyers about the research posted in the department hallways, and via the general education cultural anthropology course. Each of the twenty-two interviews (approximately one-hour long each) was recorded and transcribed by the interviewers. 
In the final year of research, I conducted follow-up interviews with students who graduated in addition to first-time interviews with other anthropology alumni. These interviews focused on the individual's experiences after college and if and how their undergraduate education influenced their personal and professional trajectory. The interviewees were recruited via Facebook and email. Each of these alumni interviews was conducted and transcribed via Zoom.

In interviews we asked students questions such as How and why did you choose to major anthropology? What do you expecting to get out of the major? What is this major like compared to other majors on campus? What are your goals and plans after college? The semi-structured interview was especially beneficial for the ethnographic approach to our research. The openended questions and general interview guide provided freedom to diverge from structured questions (Mannik and McGarry 2017, 73-74). The tactic allowed us to follow the flow of the conversation and gain an in-depth and well-rounded understanding of the individual which helped us to understand why students made certain decisions.

Our understanding of interviewing was inspired by Pierre Bourdieu’s (1999) description of interviews as a deep form of empathetic listening. Interviewing my peers was beneficial and challenging. Interviewing my peers allowed for communication that embodied a community of practice, that is, our conversations revealed our shared experiences in the major and the department and a shared understanding what it means to be an anthropology student. As a member of the major, my writings and research incorporate an insider perspective. The challenge was to interpret these interviews in a broader social and historical context.

Our sample consisted of 22 interviewees, of which 18 were anthropology majors, two anthropology minors, and two took and anthropology course and decided not to major in it. 
There were 15 women, six men, and one non-binary student. 16 students were native and 6 transfers. Nine students were seniors, nine were juniors, two were sophomores, and two freshmen.

After the interviews were completed and transcribed, I read interview transcripts and notes to identify emerging themes. These themes were discussed in regular meetings with my faculty mentor, Gina Hunter. These themes were compared with those emerging at other campuses in the AAA study at regular meetings over the summer of 2019 led by the Principle Investigator, Daniel Ginsberg. At Illinois State, some of the major themes included how students discover anthropology in general education courses, a shared sense that anthropology is misunderstood field and major, a shared sense of belonging in the department and in anthropology. In terms of what students say they gain from anthropology, students identified personal characteristics (e.g. open-mindedness) and certain professional skills (such as research skills) that that they developed as part of the major. Of their plans post-college, few students planned for a career as an anthropologist, but believed that anthropology would help them be comfortable in a global world (cosmopolitan goals) and provided other skills that would prepared them broadly for a life and careers outside of anthropology after college.

In what follows, I take up these themes individually and illustrate them with quotes from the interviews. I begin with two case studies of students I call “Jared” and "Lola” who both graduated university in spring 2019. Their stories illustrate the major themes as well as how they experienced the transition after college. 


\section{CHAPTER IV: DATA AND ANALYSIS}

I begin my analysis using case studies which allow me to provide a more complete understanding of a person's development, motivations, and goals while situating the person in the larger constraints in their lives. Then, using data from all interviewees, I broadly explore major themes such as discovery of the major, personal growth in the major, and students' imagined value of anthropology after college.

\section{The Case of Jared}

I highlight Jared’s story because he faced much adversity during his decision to study anthropology. Despite the constraints, he chose the major because it aligned with his values. Additionally, he was especially articulate about the skills anthropology offers. Jared, a senior

student whose family came to mainland United States from Puerto Rico, explains that he came to the anthropology major because all his other learning has been centered on the U.S.

Jared's parents had moved from Puerto Rico and climbed corporate ladder in order to “make a good home for themselves.” Jared explained, “They always told me that's the way that you need to get successful. And so I thought, oh, that means that I need to go into business in order to be successful.” Jared spent a year studying international business and marketing when he realized that his parents advice was "just not the case," and "the world is just so much larger, and there's so much more to do.”

After this realization, Jared took various classes in language, art, and foreign culture, trying to decide what was the best fit for him. Once he discovered anthropology, through the advice of his French teacher, he confessed to his parents that studying business "was going against every fiber of my being.” He could not tell them that anthropology would lead to a specific, profitable career, but offered that, “anthropology has so many valuable skills that you 
can't necessarily put on a resume.” This did not sit well with Jared's parents. He explained, "when I told them I was pursuing anthropology, something they'd never heard about, my mom cried. She cried, like real tears. And my dad was so mad. He didn't talk to me for a while.” I conducted an interview with Jared in the spring of his senior year. Jared, who attended high school on the north side of Chicago, reflected, "We didn't have anthropology classes in high school. So I wouldn't have known anthropology. I just went into college thinking, oh, business, a lot of people get jobs in business.” Freshman year Jared declared his major as International Business with a minor in French, but he soon realized, "I did not like what I was doing...The path that I was on wasn't right for me.” Jared sought advice from an academic advisor in the French department, “She was like, what do you really want to do with your future?” Jared confessed to her, "I want to travel, talk to people, help people.” The academic advisor responded, "what you're talking about sounds like anthropology." With a grin on his face, Jared relayed to me, "Imagine, at this time, I had never heard of anthropology. I was a sophomore...with no conception of what anthropology was at all.” He continued, “Not until somebody told me, 'I think you would be good at anthropology,' did I think that’s a possibility for me.” For Jared, a conversation with an advisor was what encouraged him to switch his academic path to a field of study he truly enjoyed.

Jared knew that anthropology had a reputation. Jared said, “unfortunately, anthropology has the rep[utation] of being one of those easy majors, you know, you just get in and get out.” The message he heard about anthropology was always, "I've got an anthropology major, what am I going to do with it?” He continued, “It's got a bad rap for that. And so I think anybody who's going into anthropology or going into the corporate world with that [degree] just needs to be wary of that.” 
Jared choose anthropology because he believed that the major would give him a unique insight into the people which will help him with "communication...relating to other people on a personal level." When asked what he hoped to get out of anthropology he said, "being in anthropology has given me the interpersonal skills that I've always wanted, or that I've always needed in like a job. You know, just being able to sit down and talk with someone face to face and get rid of most of the nervousness.” He explains that anthropology values other perspectives and has given him the skills to "able to communicate with people cross culturally, one on one." Then, Jared spoke about how he chose anthropology because it human-centered focus aligned with his own values. For example:

"The thing that anthropology is good at is putting the person first. So putting people and the personal perspective before anything. With anything that I go to later on in life, one of the things I'm always going to take with me from anthropology is thinking about the people who are affected by the decisions that people make in high positions. So no matter what, always considering the little guy in making big decisions, because I think that that's often forgotten in today's environment in general...I wasn't in it for the money, but [for] learning.”

For Jared, a degree in anthropology is about values and self-betterment, not monetary gain. When I asked Jared for his plans after college he explained, "I think it's less about the value of your degree. And more so how you choose to apply the skill set that you've gotten from the stuff in your degree." Jared is saying, life after college is about marketing yourself and your unique skill set.

Jared continued his thought, "I've gotten the same education as everyone else who has gotten a degree in anthropology here [at ISU]. And I personally feel I've gotten a lot out of it. 
Taking all these classes and opportunities...It's gotten me personal success.” Jared feels like, although he has gotten an education comparable to hundreds of other anthropology students, his experience was successful because of the unique opportunities he received. One summer, Jared was awarded an NSF REU fellowship that allowed him to travel out of state for an archeological excavation. The following year he enrolled in an ethnographic methods course and met a fellow classmate who was a PHD student in biology. He excelled in the methods course and the following year he become an undergraduate ethnographic research assistant to the biology student who was studying how people learn biology. He was later able to present his research at conferences. Jared was humble about his participation in these unexpected, but valuable experiences, he offered that these were "opportunities I reached out and grabbed... But any other students [are] just as capable as me.” Although Jared is grateful for the research experiences anthropology brought him, those opportunities are not what brought him to anthropology or what made him stay in the major. He craved the type of liberal arts education that puts an emphasis on communication, human relationships, and personal experiences.

Jared was familiar with the question, “what are you gonna do with that degree?” He has heard it from peers, friends, siblings, parents, mentors, even strangers. Often, it felt like an attack on the integrity of the major he chose or an accusation of foolishness. For him, learning how to navigate this question became part of the rite of passage into the major.

Jared's anthropology major did not make him feel intimidated for life after college. He believed, "with any field, you can go in with the right mindset and be successful.” But Jared's parents did not agree.

Jared's family's insistence on studying business was becoming a constraint on Jared's personal development. He said, since he changed his major to anthropology, "My parents never 
took me seriously. They always thought that I was going to be a failure. Well, until I started making me money... I was getting paid on a stipend from a grant [for my fieldwork] ... And for the most part, they don't still respect me for what I do.” Although Jared wished his parents would support him, he does not regret his decision. He said, "When I switched, I just knew I was really happy....and I knew that, in general, I was making the right choice for myself.” Jared’s relationship to anthropology is emotional because his choice to pursue what he loved cost his parent's respect. Despite this struggle, he never gave up on his future. He said, "I kind of just thought, no matter what, if you're passionate about something you will be successful.”

In an interview weeks before graduation Jared said, “I want to talk to people...help people...contribute back in some way.” Jared was passionate about, “diagnosing and affecting issues that arise in urban centers," the topic of his senior thesis. As graduation approached, Jared explained to me, "I just really want to contribute to a larger dialogue about issues that affect the world now. And anthropology has given me the steps to be able to understand what a lot of the issues in the world are and where they come from.”

When asked about his plans for after graduation Jared said, "Well, I see myself continuing to go to school. Because I don't think with an anthropology degree that just settling within anthropology is really going to do much. And I don't mean that in any type of way towards anybody that pursues anthropology. But, there's just limited career options, if you don't choose to continue on with your education in anthropology.” He continued explain his future goals to serve with the Peace Corps then use the Peace Corps scholarship program to fund his graduate schooling. Jared planned to study civil engineering at the graduate level and eventually secure a career in city planning "to help provide solutions to ecological problems facing urban areas.” 
Since graduation in spring 2019, Jared has secured a job at a software company in the suburbs of Chicago. In a follow-up interview in Spring 2021 he explained how this job is helping him save money before he applies to the Peace Corps. He plans to request a Peace Corps position in the community and economic development sector, which will give him experience in urban planning, his ultimate career goal.

Jared's story is an example of finding his passion and pursuing it despite financial and familial pressure. The case of Jared was uncommon in our findings. Of the three interviewees who spoke of their families refusal to support a degree in anthropology, two decided not to declare the major. The rest (19) of the interviewees didn’t mention family struggles as an obstacle to the major. Based on Mullen's socio-cultural analysis of major choice, Jared, a man of color, is unlikely to pursue a degree in anthropology. What we learn from Jared is that students have agency to choose an anthropology major despite constraints.

Jared's story shows the benefits of being part of a community of practice. After joining the community through the major, he was asked to do anthropology through his research. These experiences contributed to the community and helped Jared see himself as an anthropologist and a researcher. Although Jared's ultimate professional goal is outside of anthropology (urban development), he still believed his anthropology experiences will be broadly applicable to the world outside of anthropology.

\section{The Case of Lola}

Lola's case differs from Jared's. Lola is a transfer student, she had anthropology in high school, and she has a clear plan of what she wants to do post-graduation. Lola chose to attend ISU because the university offered program that made her a more competitive applicant for her future goal. 
For Lola, a senior white female, she came to anthropology because it was her favorite class in high school. She knew "anthropology is cool" because she liked to "talk about apes a lot” and she was "aware of the other disciplines of anthropology.” Lola transferred into ISU after two years at a small liberal arts college where she declared a major in education, but realized education was not the path for her because it did not allow for "self-expression" and required her to remove all of her piercings, cover her tattoos, follow a dress code.

She choose to transfer to ISU primarily because of her interest in the university's Peace Corps Prep Program. This Prep Program gives students a competitive boost in the highly selective Peace Corps application process. International service with the Peace Corps was Lola's guiding choice in attending the university, but after she transferred she was yet to choose a major. Since she came to ISU as a junior, she was left a limited number of programs with credit requirements that would have allowed her to graduate in the spring of her senior year (four years total). She choose to study anthropology because of her interests from high school, but also because the department requires only 34 credit hours which can be achieved in two academic years. For Lola, choosing her major as a junior, it was most important to her to just get a degree. She didn't want to spend any more time than she had to getting a college degree.

Lola, wanted a degree in anthropology to provide her with "knowledge” about cultural diversity and human universals, “cool books” that let her academically explore her niche interests, and the freedom to express herself without putting limitations on her fashion choices. What she wanted out of the major was a deeper connection with herself and a broader understanding of the human condition.

In a conversation about tuition, Lola said, "I love the liberal arts. But the privilege that comes along with it is immense.” She recognized that many students are not in a financial 
position to take out loans for a degree that does not secure a career. Lola explained, "I'm lucky enough to have financial aid. And I also have help from my parents. So I'm taking out minimal loans. If I was in a situation where I was about to drop 80 grand for an education, I would NEVER be an anthropology major. That would be one of the dumbest things I could do. I think I'd do nursing or something." She continued to explain that she sees privilege "in a lot of students in the anthropology major, but I love the understanding that is cultivated from the educational aspect of [the major].”

In response, I asked Lola if she has any ideas to improve the major. She answered, "It needs to be more niche. That's what the major needs. It needs to be split up into five majors.” Lola appreciates all four subfields but did not find the broad scope realistic. She explained that the broadness of anthropology is at odds with the job market's preference for specialization. She expressed that the connections between her anthropological education and work in environmental conservation were clear to her but translating that connection to an employer had proven difficult. She complains that the department left her "knowing a lot about a lot of topics" but without depth. Lola suggested that the undergraduate curriculum could benefit from allowing students to completely pursue one subfield.

Our interview, in the spring of 2019, was conducted days before her graduation and just ten months before Lola was scheduled to depart to Latin America as a Peace Corps volunteer working in the environmental and agricultural sector. She described how studying anthropology gave her the tools to "explain intersectionality" and the skill of "cultural competence" which will be indispensable on her journey abroad. She pointed out that she was attracted to the program's social justice course work and hands-on learning methods. In particular, she felt connected to courses on food justice and sustainability, testifying that, although she knew she wanted to 
pursue agricultural and environmental work, getting a degree in "anthropology is setting me up to understand what I want to do.”

When asked about her future plans Lola explained, "before I further my education in any way, I want to do primarily service work.” In order to effectively accomplish that goal, Lola felt she must, "learn how to fluidly integrate into any culture that I want, whether that'd be, internal, within this country, or internationally. I think my anthropology major is going to help me do that." She continued, "I think of the Peace Corps, also, as a huge ethnographic experiment... In order to really understand and do anthropology, it has to be applied.” Even though she is interested the international and intercultural experience and she wants the cache of having been a Peace Corps volunteer, she is aware of her privilege and its contradictions: “..the white savior complex involved in the whole situation is gross to me. There's like some really gross things about the kind of stuff I want to do, just solely based on my position of privilege. But like, you know, I don't know what to say, I really don't know what to say about it.” Lola's story highlights how a student can take the values and cultural awareness they've fostered throughout their anthropology education and apply that to their future work.

Lola's interview was peppered with contradictions. She said that a degree in nursing would be worth the tuition rates, but a degree in anthropology is not; yet, she said her degree in anthropology was setting her up for what she wanted to do. She explained that she loves the liberal arts, yet she complained that she has broad knowledge without depth. Additionally, her desire to fit into any culture anywhere is an example of a new kind of "cultural cosmopolitanism," a desire to be "comfortable in the world" (Werbner, 2008). Lola was aware of her privilege and wants to works in service, but she doesn't see her desire to fit in anywhere as a form of privilege. 
During a follow-up interview in Spring 2021, Lola told me about her evacuation from Peace Corps service in Latin America due to the COVID-19 pandemic. Prior to departure Lola sold her car, donated all her wordily belongings, and voided her apartment lease in preparation for spending 27 months abroad. After only 3 months abroad she was evacuated and forced to return to the U.S. with nothing but a couple thousand dollars in relocation compensation from the Peace Corps and “nowhere to go”. She said, “Peace Corps didn’t even let me get on unemployment after they sent me home...I'm not mad about it anymore but I'm definitely not looking into Peace Corps again.” Luckily, that relocation compensation was enough for her to find housing while she looked for another job. Now, she is volunteering with the Americorps program City Year. She works with high school students and describes the experiences as "unique” and "the best experience ever.” She plans to volunteer with the program for a second year as a continuation of her passion for service work.

In the following section I transition to talking about the themes that emerged in the larger sample (22 interviewees). I include new themes and I also expand on themes highlighted in Jared and Lola's stories with examples from other students.

\section{Finding Anthropology}

Understanding how students discover the anthropology major provides important background for why students choose to graduate with that degree. Anthropology is generally not taught in high schools, so many students have no exposure to the field until they come to college. In my sample 13 out of the 20 anthropology students interviewed (18 majors, 2 minors) were introduced to the major through general education courses. At Illinois State, both professors and advisors are influential in the discovery process. 
For example, Lila, a white woman in her first year at Illinois State said, "I was taking anthropology originally as a gen-ed course. But then after the first week, I was like, this is amazing. I was like, I have to do this.” Alicia, a white woman in her junior year, shared a similar story. She remembered, "I was a business major,” in her freshman year and she knew, “I definitely don't want to do business.” Although Alicia knew what she didn’t want to study, she had yet to discover her discipline of interest; she explained, “I didn’t want to change my major just to pick another major.” In the spring of her freshman year, Alicia enrolled in a general education anthropology course. She described the professor, “He’s trying to get people to change their major” because he was always talking up anthropology. She continued, “That class got me thinking,” and the next semester Alicia declared her major as anthropology.

For Gemma, an introductory biological anthropology course inspired her to change her career path and therefore her major. Gemma, a white student in her senior year, reminisced, “my first class was anthropology Human Origins and it was so interesting. I loved it from the beginning. So from there, this is something I could see myself doing...After that class, I changed [my major].” She continued, "I wanted to do something that I love and that I was interested in.” Gemma acknowledged both the anthropology professor and the course content as essential to her decision to change her major.

Another way that students hear about the major is through an academic counselor. If a student is interested in switching their current major or adding another major, it is customary to talk about this new academic path with an academic counselor. Some students talk to a career center counselor to get direction, others may directly contact the academic advisor of the anthropology program. 
Jared found the major after talking to an academic advisor in the French department. She suggested that anthropology could be a good fit for Jared and he took her advice. Another student, Cameron, was introduced to the anthropology program at a freshman seminar hosted by the anthropology department's academic advisor. This seminar was part of their first visit to Illinois State University. When Cameron arrived on campus, they received a packet with information about the various majors offering introductory seminars that day. At first, Cameron visited the marketing program's seminar but felt it was "stern and unwelcoming" so they decided to find the anthropology program's seminar. Cameron recounted, "I walked in and the advisor was wearing flip flops, cargo shorts, and an orange polo with some stains. I loved that. A dude confident enough in what he knows to show up in flip flops. At that moment, I was like, yes, sign me up!” The academic advisor's non-verbal actions acted as Cameron’s introduction to the major. The feeling of the academic advisor "being different" and "welcoming” was enough for Cameron to declare the major.

Students hear messages about their college degree from many sources (Erickson and Shultz, 1982). This ethnographic data shows that particularly influential sources include professors and academic advisors. These individuals expose the world of anthropology to students. Student's discovery stories are often intertwined with the reasons students choose to major in anthropology. This is discussed further in the following subsection.

\section{Why Undergraduates Choose Anthropology}

Once students have discovered the anthropology program, what motivates them to study anthropology throughout their college career? My findings suggest that students choose the major because they were passionate about the field and appreciated the broad perspective 
anthropology courses provide. Others were able to combine anthropology, with only 40 required credit hours, with other areas as a double major.

Students who are fascinated by anthropology's course content talk about an attraction to the "broadness" and "flexibility" of the major. The terms "broadness" and "flexibility are used interchangeably by students to refer to the number of topics covered within anthropology as a discipline and to refer to how anthropology can be applied to many areas after college. Remilda, a Latina student in her junior year, explains why she "loves the flexibility" of anthropology, "the nice thing about anthropology is that you can leave with a bachelor's, a Master's, or a PhD, and you can do anything with it...it being so open is really nice.” In these instances, when the student discusses the broadness and flexibility of the major they use "love" to describe that feeling. Students' love for the major is expressed in varying ways but expands beyond a love of the course content to include the applicability of the field to professional life.

Gemma explains, "I love having a broad major, because I'm very indecisive with what I want to do with my life. So having a lot of options is good for me.” Grace, a senior studying anthropology and peace studies, also values the holistic scope of the degree. She says, "All of these subdisciplines, I don’t want to pick one, that like why choosing a thesis topic was so difficult. Because I don't want to pick. I'm really good at thinking about, like big, broad ideas, you know, connecting all these and doing the whole interdisciplinary thing. I love that.” At Illinois State, students generally explore one subfield of anthropology through elective courses and through the senior thesis project; this was a difficult choice for Gemma.

While many students expressed a passion for anthropology, eight students explained that the institutional requirements, that is, a low number of required credit hours, also played a role in their decision of a major. Of the eight interviewees, six said the credit requirements allowed 
them to choose anthropology as a second major. The other two interviewees said anthropology was appealing because the credit requirements allowed them to graduate on time (spring senior year). This did not necessarily mean that those students did not value anthropology per se, but it was a factor in their decision to major in it.

For instance, although Lola loved anthropology, she was one of the students whose decision to major in anthropology was influenced by the credit requirements. Lola's priority was just to get a degree so she could begin her service with Peace Corps. Another student, Kim spoke about both the institutional requirements and the broadness of the major. A former education student at Illinois State changed her major to anthropology in her junior year when she realized during her clinicals that she did not want to be a teacher. "I can’t do the same thing every day,” Kim said. She knew she wanted to graduate as soon as possible, so she researched programs to find a major with a low number of required credit hours. Based on her internships at a police department and volunteer work at a local crisis hotline, she found that she still wanted to "work with people.” Earlier in her academic career, she had taken and enjoyed anthropology courses, but had not considered majoring in it. When she met with the advisor and he told her where ISU alumni were working now, she became very interested, "It was just a wide range, like from working [in insurance] to being caseworkers. It changed my view on what I saw myself doing. Now I feel like I can do whatever I want....after I graduate.” Kim values anthropology for its holistic scope and broad career options. She chose anthropology because he wanted to "graduate on time" and as a junior transfer, anthropology would allow her to get a degree "as soon as possible."

Caleb, a Latino student in his junior year, expressed concerns about the practicality of the anthropology major. He hoped to switch his major to nutritional science or another field with 
more "career options.” In a follow up interview in the fall of his senior year, he confessed that he choose to stay in the anthropology major because he wanted to graduate on time. He felt that the convenience and cost-effectiveness of graduating after four years outweighed the security (and expenses) of staying to complete another degree. For Caleb, the institutional requirements are not why he came to the major, but why he stayed in the major.

Whether it be the "love," "broadness," "flexibility," or institutional requirements that make it the right fit, students find the anthropology major along their college path and decide to study it because it is right for them; however, the decision to study anthropology is not always a painless. Anthropology undergraduates today receive mixed messages about the value of their degree. Students navigate the messages they hear from their peers, university, and family, in addition to their internal perception (Goldmacher 2011). Amidst this ocean of opinion, students experience the social and financial ramifications of their decision to major in anthropology.

Students, like Jared, are not supported by their families. Of our 22 interviewees, three discussed not being supported by their parents and two of these three decided to listen to their parents and not declare the major. Despite the lack of family support, Jared is an example of an anthropology student who was confident about his future career opportunities. For another student, Erica, choosing to major in anthropology was difficult because she was concerned about future job opportunities.

A white, non-traditional student in her late twenties, Erica joined the anthropology major after serving in the United States Army and starting a family. Erica expressed concerns about future job prospects, “I know we all have pretty pessimistic [attitudes] toward our major’s career market. It's not such a good market...I looked at the US government labor statistics and anthropology is one of the lowest in hiring.” Out of concern for the future of her family she is 
trying to take the more "practical" route of archeology. She describes archeology as "more applicable” because you can apply to a position in a museum or on a dig. Erica knows her opinion won't change statistics, but she values her degree in anthropology and thinks, "the problem is that people don’t understand how practical anthropology can be.”

In addition to these personal and professional struggles, financial concerns are, of course, a burden for many college students. Erica's tuition is covered because of her status as a Veteran. For Jared, his parents refused to pay for his schooling once he changed his major.

These struggles can harm relationships, cause concern for future career opportunities and current financial status, but they also build solidarity among the anthropology students. Anthropology students bond over the shared experiences of misunderstandings about their major, concerns about future professional life, and financial constraints. Students endure these experiences because they love anthropology.

\section{“Learning from each other:” Community of Practice Among Anthropology Students}

At Illinois State, the interview exchanges revealed a community of practice, a space that encourages academic growth and curiosity (Lave and Wenger 1991). In fact, the shared sense of concepts, values, experiences, and tools was constituted assumptions provided the foundation for the conversation. This was so pervasive and obvious that it was sometimes difficult to see and was not initially apparent to the research teams. One potential limitation of insider ethnographies is that familiarity with the context fails to arose curiosity and questioning of the phenomena at hand (OReilly 2009 112).

The concept of community of practice requires three levels: domain, community, and practice (Lave and Wenger 1991). When Lave and Wenger discuss the community, it extends outside of the local. It involved connections to various groups and resources that engage with 
similar material and practices. For students at Illinois State, their community of practice focuses on campus and occasionally extends to neighboring museums, field sites, or sharing papers at the annual national conferences for undergraduates.

Anthropology students at Illinois State share a building for all classes and faculty offices. During my time at Illinois State, I heard passing remarks such as, “oh, I live in this building” or “the classroom is my home.” One student said, "the building of anthropology, it’s such a close community. Everyone knows each other. Everyone has the same interests and goals. So I feel it's easy to call myself an anthropologist even though I don't have a degree.” This building becomes somewhat of a home for undergraduates and a domain for practicing anthropology (Lave and Wenger 1991). The hallway bulletin boards are coated with flyers that invite students to attend guest lectures, become a member of SOSA (the society of student anthropologists), join studentled events (such as a trip to the field museum in Chicago), participate in field-school, and apply for graduate programs.

The department at Illinois State hosts an environment that helps students feel like part of a community. Students have a domain in the anthropology building. They feel a sense of community with their like-minded peers and welcoming professors. They practice through sharing resources, recommending reading material, questioning each other, gossiping about the latest in anthropology news, participating in the SOSA extracurricular, and participating in undergraduate conferences.

While students talked about their the department and program and a sense of belonging, the shared practices and ways of thinking as anthropologists was sometimes left unarticulated. At Illinois State, interviews were actually suffused with references to certain theories and subjects (intersectionality, cultural relativity, anthropological understanding of race, Neanderthals) as 
well as historical figures (Franz Boas, Alfred Kroeber). There are moments of commiseration about certain professors and courses and about how misunderstood the field of anthropology is. These appear in the transcripts as “you know?” "of course.” "been there; done that!” The interviews are also filled with passages that could be seen as tangents to the interview itself, but where students shared tips and information on how to deal with certain courses and professors, when to talk to the advisor, how to deal with uncertainties about the future as an anthropology major.

One student was especially direct with her assessment of the value of both the anthropology department as well as the other anthropologists she had met along the way: "one of the most beneficial things I think about coming here to get my degree in anthropology is the other anthropologists I made contact with and learning about the different areas that you can be interested in and how diverse anthropology can be. You don't have to just like study one thing your whole life... you can do these different things. I think that what's been the most beneficial. It's the actual anthropologists that I've been in contact with, heard [from], and stuff.”

Another student spoke about the connection to others in the community: "I really connected with people (in the program) on like, on, I don’t know how to say this, like on a very emotional level. That sounds weird, but, you know... (Interviewer: Supportive). Yeah, yeah, supportive. That’s the right word. (Interviewer: They are emotional supporters). Yeah, you could tell that they're not just there to give you a grade. But like even your classmates, like it's so small and people really have, like, an understanding of other people that you might not get in other majors. People are understanding; and we are very research-based, I don't 
know about other areas, but we are research-based. Throughout most of my classes I really learned [to do research], and like I wasn’t really good at that before.”

The act of interviewing at Illinois State revealed the practicing community. The interactions between interviewer and interviewee exhibit a level of unspoken understanding because of the shared experiences among the peers. Most often, interviewers reinforced the statement of an interviewee curtailing a follow-up question. For example:

Interviewer: What is anthropology?

Interviewer: Not just about digging (up) bones.

Respondent: Usually that's enough to satisfy most people but some people will start asking questions beyond that.

Interviewer: 'What are you going to do with that?' "something I want, thank you.'

Respondent: I get that from coworkers and some like extended family, like what are you going to do after college.... I never had to deal with that from my parents.

But it's still a question, of like, ok here we go again, 'what is anthropology?'

Interviewer: Yeah the whole liberal arts are... You can't do shit with it.

Respondent: Everybody thinks social sciences and liberal arts is just kind of, it's

all not making money.

Interviewer: Doing business would...

Respondent: Right. You're not doing anything like that.

Interviewer: Totally.

Each student's undergraduate career is shaped by their academic choices. Upon choosing an area of study, a student joins a community of people who share their interest in similar 
questions or topics shaped by a specific intellectual tradition. When a student chooses their college major, they embark upon a course of study with specific requirements for learning experiences that become the foundation of a student's perspective that shapes how they approach experiences in the "real" world after graduation.

\section{“A time of personal growth:” How Anthropology Changes Students}

During interviews, students mentioned the skills they gain, but many students focused on personal growth as a value of anthropology. When students talked about developing understanding, perspective, awareness, and skills, it was wrapped up in conversation about their self-development.

For example, Cameron, a non-binary Philippine student in their junior year double majoring in History and Anthropology, highlighted how anthropology allowed them the space to grow in their creativity. Cameron explained, "anthropology is very logical. But it gives you so much room to not fit in that box.” This creative freedom was an important contributor to Cameron’s decision to study anthropology; Cameron described the Department of Anthropology and its faculty as "welcoming" because "they give students so much room to grow."

Cameron communicated that organization has been their long-time strength, but studying the liberal arts allowed them to strengthen other areas of their life, such as critical thinking and flexibility. Cameron brought up their experiences with the anthropology course work, attesting, "going through those classes really helped me grow as a person." Cameron felt that the professors in the anthropology department had unique ways of teaching course content that required Cameron to be flexible. Cameron reflected upon their time as a student in the department, "these past two and a half years have been my time of growth and getting to know me as a person.” 
Cameron's experiences tell a story of personal development. During a follow-up interview in the winter of Cameron's senior year, they expressed gratitude for all of the growth they encountered throughout their undergraduate studies in anthropology; they hope to continue on this path of self-growth as they attend graduate school in Korea.

Lila, a white student in her freshman year, switched from a biology major to a double major in Anthropology and Political Science. In addition to her studies, Lila plays in the university band and is involved in many extracurriculars on campus. She claims, "my goal in college is not to build myself a career path. If I work on building up my own life, then a career path will blossom out of that.”

Lila explained that anthropology allows her to, "really work on myself as a person and find out what's important to me.” She continues, “even if I don't end up in a career in anthropology, it's just going to help me to better understand...and be aware of how I act.” Lila stated that chose to discontinue her studies of biology and pursue anthropology because it "affects me in my daily life...learning about different cultures and the anthropological perspective is going to help me so much more in my future.”

Lila's story is one of growth through self-awareness and personal competency. Although Lila hopes to do future work with international politics, she prioritizes "building [her]self” over "finding a career" during her time at college.

These ethnographic stories depict how anthropology helped students grow personally. Many students echo the messages of Cameron and Lila's stories. For instance, when asked to describe anthropology in one word, Violet, a Latina student in her junior year, chose "sanctuary." Violet explains, "anthropology fosters a safe environment to really say what you want, but also allow for constructive criticism...It's learning about you.” Mary, a white woman in her 
sophomore year, remarks, "anthropology gets you out of your own bubble.” Caleb, a Latino student in his junior year, expresses that learning about the culture through anthropology was "revolutionary to me." He claims his anthropology experience gave him the "power to see others in me.”

These students chose anthropology because they are concerned with how college, and specifically, a major in anthropology, can help them become a well-rounded person. They view college as an opportunity for personal growth, not just a preparation for the work force. This idea is discussed in Arnett and Murray's (2019) book, Emerging Adulthood, which suggests college acts as a time for personal discovery. This personal exploration is primary to future goals and pursuits. Students need to discover who they are before they can settle on what they want to do for a career (Arnett and Murray 2019).

Anthropology students are inspired by the values and morals anthropology instills in its students. When students are asked about why they choose anthropology, they answered with “communication” or "perspective” or "self-betterment.” These values, not a promise of a secured career, are what students want out of the major.

\section{“There's a lot you can do with it:” Students Talk About Life After College}

Unlike a more narrowly vocational degree, a degree in anthropology does not prepare you for one specific career (e.g. accounting, elementary education, nursing). Students appreciate that a degree in anthropology does not tie them down to a particular career path, but instead gives them the tools to apply their skills and values to multiple areas of interest. Some students have a plan to apply these tools and other students just have faith that they will find a job.

Students were intimidated by deciding what to do in their future and anthropology allows them to get a degree without choosing a path. One student said, "[I] could take the things [I] 
learned in anthropology and apply them really anywhere.” For this student, it is comfortable to be in a major that allows for flexibility in their future plans. One student said, “I don’t know where to work. I don't know what places I could work at. Except for museums and universities. I don’t know about any other different types of places.” This student was so focused on graduating that they had not considered a path for themselves in life after college. My research partner, Abigail Ma, termed this "faith" in the anthropology major. Some students have the privileged position to choose a degree without consideration for future work. In 2008, during the time of the financial crisis, Amy Goldmacher found, "Current and former students, having internalized neoliberal and anthropological beliefs and values, feel a sense of having to choose between making a living or pursuing anthropology beyond the bachelor's degree” (2011, 116). In contrast, in 2018, students at Illinois State expressed "faith" that their degree had broad applications and would serve them in life after college.

I view this faith as an example of college as a liminal space, an extension of the adolescent stage of life and a time for self-discovery, as described by Arnett and Murray in Emerging Adulthood and Higher Education (2019). This personal exploration is primary to future goals and pursuits. Students need to discover who they are before they can settle on what they want to do for a career (Arnett and Murray 2019).

Choosing a major that does not secure a career is a way of delaying adulthood. Students wish to put off these adult choices as long as possible. One student said, "I will for sure go to graduate school. It helps extend the time.” Many students responded this way when asked about a five year plan. Anthropology gives students an immediate purpose; getting their degree achieves a goal while also preventing them from choosing a professional path for adulthood. 
Another ISU student, Brenda, changed her major many times, finally settling on psychology and anthropology. When asked about her opinion of anthropology, she replied, "I look at the world so differently now, because in psychology you can't get the perspective that you get in cultural anthropology and vice versa, you know? You need a cultural side of the person and the psychological side. So that's what I really liked about cultural anthropology, where you can really combine it with counseling, social work and what I want to go into, you know.” In her future, Brenda plans to "take a year off” to work as a counselor at a summer camp between graduation and the commencement of graduate school. After receiving a graduate degree in counseling, she wants to work as an art therapist. Brenda's experience testifies to how anthropology complements her other discipline and her future plans.

A degree in anthropology does not necessarily mean a future in anthropology. For students like Jared and Brenda, anthropology acts as a stepping-stone to graduate school and a career in another field. For students with uncertain plans, their faith led them to believe in the broad applicability of anthropology.

Each of the interviewees indicated that anthropology helped them cultivate values and perspectives they can apply in their life after college, such as cross-cultural understanding. For instance, Caleb, a multilingual Latino in his junior year, discussed plans to pursue a future as an Officer in the United States Air Force. Caleb hopes to travel and raise a family in different countries, environments, and cultures. He values his background in linguistic anthropology because he believes it will assist him in understanding the intricacies of language and respectful communication with others outside of his own culture. Similarly, Lola talked about being able to “fluidly integrate into any culture.” Students like Caleb and Lola, whose passion is international service, expressed the desire to travel and feel "at home in the world.” For them, anthropology is 
a route to becoming "cultural cosmopolitans." The idea of cultural cosmopolitanism emphasized "empathy, toleration, and respect for other cultures and values" and about "reaching out across cultural differences to through dialogue, aesthetic enjoyment, and respect; of living together with difference" (Werbner 2008, 2).

Another student, Ivy, a white woman in her freshman year, double majoring in Political Science and Anthropology, hopes to work for an international organization and asserted that her education in anthropology would provide her with more humility and open-mindedness in her workplace. Students interested in archeology, including Liam and Erica, explain how they will be able to apply values such as hard work and respect in their future careers discovering and cataloging historical artifacts.

All of the stories presented show anthropology students' desires to work effectively in diverse environments where they can apply cross-cultural understanding, and achieve career success while living their values. This research suggests that students in anthropology want to develop their values and perspectives before they decide on a career path. While many students were felt nervous and unsure about their futures, this is likely not unique to anthropology majors. This mindset echoes the writings of Guy Standing in The Precariat Charter (2011) which say finding a career after college is challenging no matter what you studied. 


\section{CHAPTER V: CONCLUSIONS}

This research project was born out of a desire to answer to the question: "What are you going to do with that degree?” In this thesis, I have provided a theoretical framework to contextualize why individuals (i.e. parents, peers, etc.) feel compelled to ask that question. The history of the university and the effects of neoliberalism on the contemporary university help explain why attending college has become about getting a job. But anthropology students don’t want a vocational education. They want a liberal arts education; and they believe this liberal arts training prepares them for life after college.

Anthropology has given students the confidence to brave the college to work force transition. Students understand that a bachelor's degree in anthropology is not a direct path to a career. This is part of the "broadness" and "flexibility" that attracts students to the anthropology major.

Unlike Goldmacher's findings, students at Illinois State do not feel they have to choose between anthropology and a making a living. They have faith that the anthropology degree will lead them to a job. What they "love about [the major]" is that it does not commit them to a particular career path. Even when they have no concrete plans, students do not express worry about their futures. They believed that their major would bring them to "personal success" because anthropology's broad scope can be “applied to anything.” Students had faith that their anthropology major would benefit them personally, professionally, and financially.

In their futures, student plan to use the cross-cultural skills they obtained in anthropology to "give back," join "service” organizations, and feel “at home” in the world. These goals are concepts, and in many cases, not concreate plans. The lack of commitment to a future field makes students comfortable. It allows them to prolong adulthood decisions and exist in college's 
liminal space (Arnett and Murray 2019). Anthropology students are not focused on life after college but instead focused on using college as a time for personal growth and development.

Conducting this research has given me a unique insight into the thoughts and experiences of anthropology undergraduates at Illinois State University. Students have plans to apply their degree to fields outside of academia. Only five of the 22 students interviewed have attended graduate school and only four others (nine total) spoke about it as an option. Statistics from the U.S. Department of Education prove that the majority (59\%) of students with an anthropology degree have no plans to become a professional anthropologist or attend graduate school (Choy 2008).

Students like Lola, Erica, and Caleb spoke of concerns about their future job prospects. Lola acknowledged her privileged position as an anthropology student. She said that she would have studied "nursing" if she was in a lesser privileged financial position. Although she loves anthropology she expressed concerns about translating her anthropology knowledge to professional environments. She feels like she doesn't know what to do with her all of her knowledge that lacked depth. Erica feels like she can only secure a job in archeology and Caleb only stayed in the major because he couldn't afford the time or money to obtain a second degree in nutritional science.

Students, like Lola, who express concerns about being able to apply their degree in professional life was more common among our interviewees. Of the 20 interviewees with a degree in anthropology, five explicitly expressed concerns about the job market for anthropologists. The rest of the students, like Jared, understood that anthropology was not directly linked to a career, but this did not make them concerned about their position in the job market. All but seven of these students spoke of no concert plans for life after college. They 
spoke of options, a general direction their future might take, but offered no concrete plans. These students had faith that they will get a job with their anthropology degree. In addition to faith, these students were focused on being in college more than life after graduation. For them, college, and specifically their degree in anthropology, was a time for self-discover. They viewed college as a liminal space where they could explore and grow, not as a means to getting a career (Arnett and Murray 2019).

Based on these findings I have recommendations for anthropology departments. Students would benefit from intentional guidance about how to translate anthropology skills to the job market. This could take many forms including career-oriented language used by faculty, futureoriented coursework, student relationships with alumni, and resources for anthropology students at university career centers. Additionally, I suggest that the department allow students the option to receive credit for an internship or job. This internship or job could be accompanied with a course that guides students in the application of their anthropological skills to non-academic environments. This option would allow senior students to graduate with more than just "faith" in the major. It would benefit student's futures by giving them real-world experience in translating their anthropology skills to employers.

Finally, The Institute for the Future predicts that $85 \%$ of the jobs available in 2030 do not even exist yet (AL-Hashimi 2017). Given the increase in technologically dominated fields, the growing expectations of not yet invented professions, and the continually shifting job market, there is a growing importance for degrees that focus on transferable skills. The kind of crosscultural, deeply historical, wide-ranging knowledge that anthropology provides sets students up to succeed in this shifting job market. 


\section{REFERENCES}

Abel, Jaison R. and Deitz, Richard and Su, Yaqin. 2014. Are Recent College Graduates Finding Good Jobs? Current Issues in Economics and Finance, Vol. 20, No. 1, 2014. Accessed April 1, 2021. https://ssrn.com/abstract=2378472. https://papers.ssrn.com/sol3/papers.cfm?abstract_id=2378472

AL-Hashimi, Abeer, et. al. 2017. Future of Work. Institute for the Future. Accessed April 1,2021.https://www.iftf.org/fileadmin/user_upload/images/ourwork/Tech_Horizons/realiz ing_2030_future_of_work_report_dell_technologies.pdf

“Anthropology,” Microsoft Encarta. Online Encyclopedia. Published 2003. Accessed April 1, 2021. http://individual.utoronto.ca/boyd/anthro7.htm\#: :text=Anthropology\%20traces \%20its\%20roots\%20to,the\%20organization\%20of\%20human\%20society.\&text=They\%2 0treated\%20these\%20questions\%20as,were\%20the\%20creations\%20of\%20God.

Armstrong, Elizabeth and Laura Hamilton. 2013. Paying for the Party: How College Maintains Inequality. Cambridge, MA: Harvard University Press.

Arnett, Jeffrey and Murray, Joseph. 2019. Emerging Adulthood and Higher Education: A New Student Development Paradigm. Routledge, NY.

Brennan, Timothy. 1997. At Home in the World: Cosmopolitanism Now. Cambridge, MA: Harvard University Press.

Breitborde, L.B. 1989. “The Don, the Dean, and the Department Major: Competing Models for the Anthropology Major.” Urban Anthropology and Studies of Cultural Systems and World Economic Development (18): 5-16. 
Brighouse, Harry. 2019. How Can We Understand “Liberal Arts Education”? The Andrew Mellon Foundation. https://mellon.org/news-blog/articles/how-can-we-understandliberal-arts-education/

Caine, Barbara. 2010. "Writing Cosmopolitan Lives: Joseph and Kwame Anthony Appiah." History Workshop Journal (70): 152-71. Accessed April 1, 2020. www.jstor.org/stable/40981163.efault\%3A552dcb1bc8f5b4783425e26520bbae8f\&seq=1 \#metadata_info_tab_contents

Choy, S.P, Bradburn, E.M. 2008. Ten Years After College: Comparing the Employment Experiences of 1992-93 Bachelor's Degree Recipients With Academic and CareerOriented Majors. National center for Education Statistics, Institute of Education Scences, U.S. Department of Education. Washington DC.

“Date Point Report.” National Center for Education Statistics. US Department of Education. Published 2017. Accessed April 1, 2021. https://nces.ed.gov/pubs2018/2018434.pdf Elcioglu, E.F. 2010. Producing Precarity: The Temporary Staffing Agency in the Labor Market (33): 117. Accessed April 1, 2021. https://doi.org/10.1007/s11133-010-9149-x

Erickson, Fredrick and Jeffrey Shultz. 1982. Counselor as Gatekeeper: A Social Interaction in Interviews. New York: Academic Press.

Faust, Drew Gilpin. 2009. “The University’s Crisis of Purpose.” NEW YORK TIMES BOOK REVIEW.

Ferrall, Victor. 2011. “The Declining Demand for Liberal Arts Education.” Liberal Arts at the Brink (40-59). Cambridge, Massachusetts; London, England: Harvard University Press. www.jstor.org/stable/j.ctt24hhk8.7 
Fowlder, Don, and Nancy Parezo. 2007. "In the Anthropology Building.” Anthropology Goes to the Fair: The 1904 Louisiana Purchase Exposition: 295-323. London: University of Nebraska Press. doi:10.2307/j.ctt1djmg8d.18.

Freeman, Harris, and Gonos, George. 2011. The Challenge of Temporary Work in Twenty-First Century Labor Markets: Flexibility with Fairness for the Low-Wage Temporary Workforce. The University of Massachusetts.

Galotti, K. M. 1999. Making a "major" real-life decision: College students choosing an academic major. Journal of Educational Psychology, 91(2), 379-387. https://doi.org/10.1037/00220663.91.2.379 https://psycnet.apa.org/record/1999-03660-018

Galotti, Kathleen M., Elizabeth Ciner, Hope E. Altenbaumer, Heather J. Geerts, Allison Rupp, and Julie Woulfe. 2006. "Decision-making styles in a real-life decision: Choosing a college major." Personality and Individual Differences 41, no. 4 : 629-639. Accessed April 1, 2021. https://www.sciencedirect.com/science/article/pii/S0191886906001206?casa_token=_I9rph0GlsAAAAA:zgJ5jGYC6JuqnTfKXx3s5SVLnHEwG3IGbFFney0MmMsNw6T4dZ qD3-3UmczSzgp2vJQ5mwKI5-U

Ginsberg, Daniel. 2019. Trends in Anthropology Bachelor’s Degrees: A Review of Federal Data. Arlington, VA: American Anthropological Association.

Goldmacher, Amy. 2011. “'Something You Love and Something More Practical’: Undergraduate Anthropology Education in the Neoliberal Era.” Dissertation Abstracts International Section A: Humanities and Social Sciences. ProQuest Information \& Learning. 
Gusterson, Hugh. 2017. "Homework: Toward a Critical Ethnography of the University.” American Ethnologist 44 (3): 435-50.

Hacker, Jacob. 2008. The Great Risk Shift: The New Economic Insecurity and the Decline of the American Dream. New York: Oxford University Press.

Heller, Henry. 2016. “The Neoliberal University.” The Capitalist University: The Transformations of Higher Education in the United States since 1945: 171-203. London: Pluto Press. Accessed April 1, 2021. Dio: 10.2307/j.ctt1gk07xz.9.

Jackson, Palmyra; Nogueras, Katrina; Ginsberg, Daniel. 2017. A Review of Undergraduate Learning Outcomes in Anthropology. Arlington, VA. American Anthropological Association.

Kashtan, Miki. 2017. “Why Patriarchy is Not About Men,” Psychology Today. https://www.psychologytoday.com/us/blog/acquired-spontaneity/201708/why-patriarchyis-not-about-men

Katerberg, Will. 2016. The Liberal Art - Present, Past, and Future. Historical Horizons. https://historicalhorizons.org/2016/02/12/the-liberal-arts-present-past-andfuture/\#: :text=The\%20liberal\%20arts\%20go\%20back,(in\%20the\%20English\%20langua ge).

Kofman, Eleonore. 2005. “Figures of the Cosmopolitan.” Innovation: the European Journal of Social Science Research.

Loo, Robert. 2000 A Psychometric Evaluation of the General Decision-Making Style Inventory. Personality and Individual Difference, Volume 29, 5. https://doi.org/10.1016/S01918869(99)00241-X . https://www.sciencedirect.com/science/article/abs/pii/S01918869 $9900241 X$ 
Mannik, Lynda, and Karen McGarry. 2017. Practicing Ethnography : A Student Guide to Method and Methodology. North York, Ontario, Canada : University of Toronto Press. Merriam-Webster.com Dictionary, Merriam-Webster, “Liberal arts.” Accessed April 1, 2021. https://www.merriam-webster.com/dictionary/liberal\%20arts. Accessed 15 Feb. 2021.

Mullen, Ann L. 2014. "Gender, Social Background, and the Choice of College Major in a Liberal Arts Context.” Gender and Society 28, no. 2: 289-312. Accessed January 22, 2021. http://www.jstor.org/stable/43669876.https://www.jstor.org/stable/43669876?Search=yes \&resultItemClick=true\&searchText=choosing $+\mathrm{a}+$ major\&searchUri=\%2Faction\%2FdoBa sicSearch\%3FQuery\%3Dchoosing\%2Ba\%2Bmajor\&ab_segments=0\%2Fbasic_SYC5187_SYC-5188\%2F5188\&refreqid=fastlydefault\%3A8a8261a3fdbda9b3297f4525f90 fcf38\&seq=1\#metadata_info_tab_contents

Newman, Katherine. 1993. Declining Fortunes: The Withering of the American Dream. New York: Basic Books.

Nunley, John M., Adam Pugh, Nicholas Romero, and R. Alan Seals. 2017. "The effects of unemployment and underemployment on employment opportunities: Results from a correspondence audit of the labor market for college graduates." ILR Review 70, no. 3: 642-669.

Redden, Elizabeth. 2016. “International Agent Use Expanding.” Inside Higher Ed. https://www.insidehighered.com/news/2016/06/02/survey-results-show-growthcontroversial-practice-working-international-recruiting.

Reshmi Dutt-Ballerstadt. 2019. Academic Prioritization or Killing the Liberal Arts? Inside Higher Ed. https://www.insidehighered.com/advice/2019/03/01/shrinking-liberal-artsprograms-raise-alarm-bells-among-faculty 
Russell W. Rumberger. 1984.“The Job Market for College Graduates,” 1960-90, The Journal of Higher Education, 55:4, 433-454, DOI: 10.1080/00221546.1984.11780659. 20https://www.tandfonline.com/doi/abs/10.1080/00221546.1984.11780659?journalCode $=$ uhej

Standing, Guy. 2011. The Precariat: the New Dangerous Class. London: Bloomsburg Academic. Skinnell, Ryan. 2013. "Institutionalizing Normal: Rethinking Composition's Precedence in Normal Schools." Composition Studies 41, no. 1: 10-26. http://www.jstor.org/stable/43501829. https://www.jstor.org/stable/43501829?Search=yes\&resultItemClick=true\&searchText=h istory+normal+colleges\&searchUri=\%2Faction\%2FdoBasicSearch\%3FQuery\%3Dhistor y\%2Bnormal\%2Bcolleges\&ab_segments=0\%2Fbasic_SYC-5187_SYC5188\%2F5188\&refreqid=fastlydefault\%3Adc2c6574431f32fc2deb01144e55f214\&seq=1\#metadata_info_tab_contents

Tax, Sol. 1977 (1964). “The Anthropological Tradition,” in Sol Tax and Leslie G Freeman, Eds. Horizons of Anthropology (second edition), pp. 1-20. Chicago, IL: Aldine.

Thelin, John. 2004. A History of American Higher Education. The John Hopkins University Press.

Voegelin, Erminie. 1950. “Anthropology in American Universities.” American Anthropologist 52 (3): 350-391. https://www.jstor.org/stable/664499

Werbner, Pnina. 2008. Anthropology and the New Cosmopolitianism. ASA Monographs 45.Berg Publishing, Newyork, NY. 
Weyeneth, Robert R., and Daniel J. Vivian. 2016. "PUBLIC HISTORY PEDAGOGY: Charting the Course: Challenges in Public History Education, Guidance for Developing Strong Public History Programs." The Public Historian 38, no. 3: 25-49. doi:10.2307/26420839. Accessed April 1, 2021. https://www.jstor.org/stable/26420839?Search=yes\&resultItemClick=true\&search Text=history+normal+colleges\&searchUri=\%2Faction\%2FdoBasicSearch\%3FQuery\%3 Dhistory\%2Bnormal\%2Bcolleges\&ab_segments=0\%2Fbasic_SYC-5187_SYC5188\%2F5188\&refreqid=fastly-d “2019-2020 Undergraduate Catalog.” Illinois Articulation Initiative. Illinois State University. Accessed April 1, 2021. https://illinoisstate.edu/downloads/catalog/gen_ed.pdf “2019-2020 Undergraduate Catalog: Sociology-Anthropology.” Illinois State University. Accessed April 1, 2021. https://illinoisstate.edu/downloads/catalog/soa/pdf “2020 Scorecard Illinois State University.” US Department of Education. Accessed April 1, 2021. https://collegescorecard.ed.gov/school/?145813-Illinois-State-University “Illinois State Normal University.” Illinois State University. Accessed April 1, 2021. https://traditions.illinoisstate.edu/isnu/ 